\title{
SISTEM PENDUKUNG KEPUTUSAN DALAM PENINGKATAN JUMLAH PRODUKSI JAMUR TIRAM PUTIH MENGGUNAKAN LOGIKA FUZZY
}

\author{
Muhammad Yasin Simargolang ${ }^{1}$, Helmi Fauzi Siregar ${ }^{2}$ \\ 1,2,3 Program Studi Teknik Informatika, Universitas Asahan \\ Jl. Jend. Ahmad Yani, Kisaran, Universitas Asahan \\ muhammadyasins@gmail.com ${ }^{1}$, fauzi.helmi.hf@gmail.com²
}

\begin{abstract}
White oyster mushroom cultivation is a micro business which is mostly in the territory of Indonesia is very good and suitable because the temperature is suitable for the growth of various types of mushrooms. At this time it can be cultivated in a mushroom house. For optimal mold growth, temperature and humidity must be maintained according to the conditions of their natural habitat. The amount of oyster mushroom production can be increased by taking into account the factors that influence the growth of the oyster mushroom itself. Even farmers can experience failure in production or often called crop failure. Decision support systems can be used in determining the increase in production. In this study also implemented the fuzzy logic method in Increasing the production of oyster mushrooms. It is hoped that farmers can use it to increase the production of oyster mushrooms and prevent crop failure. Application results are expected to be a decision support system for farmers in the maintenance and production of oyster mushrooms. Starting
\end{abstract} from determining the planting media, see the temperature and humidity.

Keywords - Fuzzy Logic, Decision Support System, Increase, Amount of Production and White Oyster Mushrooms

Abstrak - Budidaya jamur tiram putih merupakan usaha mikro yang sebagian besar di wilayah Indonesia sangat bagus dan cocok, karena temperaturnya yang sesuai untuk pertumbuhan berbagai jenis jamur. Pada saat ini dapat dibudidayakan pada rumah kumbung. Agar pertumbuhan jamur dapat optimal maka temperatur dan kelembaban harus dijaga sesuai kondisi habitat alaminya. Jumlah produksi jamur tiram dapat ditingkatkan dengan memperhatikan faktor-faktor yang mempengaruhi pertumbuhan jamur tiram itu sendiri. Bahkan para petani dapat mengalami kegagalan dalam produksi atau sering disebut gagal panen. Sistem pedukung keputusan dapat digunakan dalam menentukan peningkatan produksi. Dalam penelitian ini juga di implementasikan metode logika fuzzy dalam Peningkatan produksi jamur tiram. Diharapkan dapat digunakan para petani dalam Peningkatan produksi jamur tiram dan mencegah terjadinya gagal panen. Hasil Aplikasi yang diharapkan dapat menjadi sistem pendukung keputusan kepada petani dalam pemeliharaan dan produksi jamur tiram. Dimulai dari menentukan media tanam, melihat temperatur dan kelembaban.

Kata kunci - Logika Fuzzy, Sistem Pendukung Keputusan, Peningkatan, Jumlah Produksi dan Jamur Tiram Putih

\section{PENDAHULUAN}

Pada perkembangan teknologi pada saat sekarang ini, banyak petani dapat meningkatkan usaha mereka dalam berbagai hal usaha dengan kategori usaha mikro. Salah satunya usaha mikro adalah budidaya jamur tiram, banyak petani dalam melakukan usaha tersebut dengan cara mengikuti pelatihan-pelatihan yang dilakukan kelompok tani dan melihat berbagai cara budidaya jamur tersebut.

Budidaya Jamur Tiram Putih merupakan usaha mikro yang sebagian besar di wilayah Indonesia sangat bagus dan cocok, karena temperaturnya yang sesuai untuk pertumbuhan berbagai jenis jamur. Jamur tiram merupakan habitat alami di hutan. Pada saat ini dapat dibudidayakan pada rumah jamur. Agar pertumbuhan jamur dapat optimal maka temperatur dan kelembaban harus dijaga sesuai kondisi habitat alaminya. Temperatur dan kelembapan sangat mempengaruhi jumlah produksi jamur tiram. Temparatur dan kelembapan yang sesuai pertumbuhan jamur tiram dapat meningkatkan jumlah produksi. Temparatur dan kelembapan yang tidak sesuai akan mengakibatkan kerugian bahkan gagal panen.

Pemanfataan logika fuzzy telah dilakukan berbagai peneliti dalam implementasinya. Penelitian tersebut antara lain mencakup bidang-bidang diluar dari teknologi informasi maupun cabang sistem cerdas itu sendiri. Seperti menentukan jumlah produksi dalam membantu pengambilan keputusan.

Dari kasus tersebut, maka peneliti mengambil judul penelitian "Sistem Pendukung Keputusan Dalam Peningkatan Jumlah Produksi Jamur Tiram Putih Menggunakan Logika Fuzzy". Hasil dari penelitian ini diharapkan dapat digunakan oleh para petani jamur tiram putih.
A. Aspek Lingkungan Sebagai Syarat Tumbuh Jamur Tiram
Syarat tumbuh jamur tiram meliputi beberapa parameter, terutama temperatur, kelembapan relatif, waktu, kandungan $\mathrm{CO} 2$, dan cahaya. Parameter tersebut memiliki pengaruh yang berbeda terhadap setiap stadium atau tingkatan, misalnya terhadap pertumbuhan miselia pada substrat tanam, pembentukan primordia (bakal kuncup) jamur, 
pembentukan tubuh buah, siklus panen, dan terhadap nilai BER atau perbandingan antara berat hasil jamur dengan berat substrat log tanam jamur[1].

Dalam penelitian N. Widyastuti and D. Tjokrokusumo menghasilkan data dalam pembentukan tubuh buah, yaitu sebagai berikut[1].

1. Temperatur Inisiasi Pertumbuhan $\left(21^{\circ} \mathrm{C}-28^{\circ} \mathrm{C}\right)$

2. Kelembapan $(90 \%-95 \%)$

3. Cahaya (500-1000 lux)

B. Sistem Pendukung Keputusan

Kusrini menyebutkan Sistem Pendukung Keputusan merupakan sistem informasi yang menyediakan informasi yang bersifat pengambilan keputusan[2].

Sistem pendukung keputusan menggunakan logika fuzzi telah dilakukan oleh beberapa peneliti. Logika fuzzi dapat dikategorikan sebagai sistem pendukung keputusan ketika solusi atau hasil yang diperoleh dari perhitungan logika fuzzi dapat dijadikan suatu ketupusan.

\section{Konsep Dasar Logika Fuzzy}

Menurut Suyanto[3] Teori tentang fuzzy set atau himpunan samar pertama kali dikemukakan oleh Lotfi Zadeh sekitar tahun 1965 pada sebuah makalah yang berjudul 'Fuzzy Set'. Setelah itu, sejak pertengahan 1970-an, para peneliti Jepang berhasil mengaplikasikan teori ini kedalam permasalahan teknis[2].

Menurut Sulistiyo Widodo[4] Ada beberapa jenis metode fuzzy yaitu, fuzzy inference system yang berisi metode-metode untuk melakukan inferensi fuzzy, antara lain metode Tsukamoto, Mamdani, dan Sugeno. Sedangkan fuzzy clustering berisi metode fuzzy cmeans, substractive clustering, dan membentuk FIS dengan fuzzy subtractive clustering. Fuzzy Database berisi basisdata fuzzy dengan model Tahani, dan Umano[2].

D. Metode Mamdani

Menurut Chabibi Aulia Rahman Al Hasmy[5], metode mamdani sering juga dikenal dengan nama metode Max-Min. Metode ini diperkenalkan oleh Ebrahim Mamdani pada tahun 1975. Untuk mendapatkan output, diperlukan 4 tahan terbobot[2] :

1. Pembentukan himpunan fuzzy

Pada metode Mamdani, baik variabel input maupun variabel output dibagi menjadi Satu atau lebih himpunan fuzzy.

2. Aplikasi fungsi implikasi

Pada metode Mamdani, fungsi implikasi yang digunakan adalah Min.

3. Komposisi aturan

Tidak seperti penalaran monoton, apabila sistem terdiri dari beberapa aturan, maka inferensi diperoleh dari kumpulan dan korelasi antar aturan. Ada 3 metode yang digunakan dalam melakukan inferensi sistem fuzzy, yaitu : Max, Additive dan Probabilistik OR (PROBOR).

4. Penegasan (Defuzzy)

Input dari proses defuzzikasi adalah suatu himpunan fuzzy yang diperoleh dari komposisi aturan-aturan fuzzy, sedangkan output yang dihasilkan merupakan suatu bilangan pada domain himpunan fuzzy tersebut. Sehingga jika diberikan suatu himpunan fuzzy dalam range tertentu, maka harus dapat diambil suatu nilai crisp tertentu sebagai output

\section{METODE PENELITIAN}

Penelitian ini disusun sebagai penelitian induktif yakni mencari dan mengumpulkan data yang ada di lapangan dan penelitian-penelitian yang telah dilaksanaan dengan tujuan untuk mengetahui data-data yang mendukung dalam menentukan kualitas jamur tiram terbaik.

A. Pengumpulan Data

Pengumpulan data merupakan hal yang sangat penting dalam sebuah penelitian. Dalam penelitian ini pengumpulan data penulis lakukan melalui :

1. Jurnal

Jurnal - jurnal yang penulis jadikan sebagai referensi adalah jurnal yang berkaitan dengan logika Fuzzy, dan yang berhubungan dengan judul yang penulis bahas.

2. Buku yang berhubungan dengan penelitian yang dilakukan Buku yang penulis gunakan sebagai referensi adalah buku yang berkaitan dengan judul yang penulis bahas.

3. Penelitian Laboratorium (laboratory research)

Penelitian laboratorium ini bertujuan untuk melakukan pengujian terhadap penerapan logika Fuzzy dalam peningkatan jumlah produksi jamur tiram. Pada penelitian laboratorium ini tidak terlepas dari piranti atau perangkat yang digunakan, dimana perangkat ini dapat digunakan untuk membantu penulis dalam melakukan pengujian. Adapun perangkat yang digunakan dalam penyusunan penelitian ini yaitu :

a. Sistem Operasi Microsoft Windows 7

b. Browser dan xampp.

c. Dan beberapa pendukung perangkat lunak lainnya.

B. Identifikasi Masalah

Berikut ini identifikasi masalah dalam sistem pendukung keputusan peningkatan jumlah produksi adalah :

1. Peningkatan jumlah produksi jamur tiram putih

2. Hasil implementasi logika fuzzy dalam Peningkatan jumlah produksi jamur tiram putih 


\section{Analisa Sistem}

Setelah pengumpulan data dan identifikasi selesai dilaksanakan, maka langkah berikutnya dilakukan adalah analisis terhadap logika Fuzzy. Hal ini bertujuan untuk melakukan pembentukan fungsi keanggotaan dari aturan logika Fuzzy. Sehingga akan memudahkan penulis di dalam melakukan analisis berikutnya.

\section{Perancangan Sistem}

Pada tahap ini akan membahas tentang perancangan dari model sistem dengan menentukan rancangan input, proses, dan output yang akan digunakan dalam aplikasi proteus. Dalam perancangan sistem ini hal-hal yang akan dilakukan adalah :

1. Menentukan Semesta Pembicaraan

Pada objek yang diteliti diperoleh dari studi pustaka dan studi kasus pada rumah kumbung jamur pada pengumpulan data.

2. Menentukan Input

Input diperoleh merupakan faktor-faktor pendukung dalam Peningkatan jumlah produksi.

3. Menentukan Output

Menentukan output yang merupakan sistem pendukung keputusan dalam Peningkatan jumlah produksi jamur tiram putih.

E. Implementasi dan Pengujian

1. Implementasi Sistem

Tahapan berikutnya yang akan dilakukan dalam penelitian ini adalah melakukan implementasi dari sistem yang telah dirancang. Pada implementasi sistem ini penulis akan membuat menggunakan metode logika fuzzy dalam menentukan jumlah produksi jamur tiram putih dan berbasis WEB.

2. Pengujian Sistem

Pada tahap ini akan diuji sistem yang telah dibuat tadi. Dengan melihat kemampuan dari sistem tersebut apakah sudah sama dengan ketentuan yang telah ada dan sesuai dengan yang diharapkan. Kemudian melihat apakah hasil analisis metode logika Fuzzy dapat di implementasikan.

\section{HASIL DAN PEMBAHASAN}

Dari penelitian yang telah dilakukan oleh $\mathrm{N}$. Widyastuti and D. Tjokrokusumo dapat ditentukan variabel input yaitu Temperatur, Kelembapan, Cahaya dan untuk variabelnya output berupa jumlah produksi rata-rata per log tanam yang digunakan dalam peningkatan produksi jamur putih. Untuk lebih jelasnya dapat dilihat pada tabel berikut :

\section{A. Semesta Pembicaraan}

Untuk menentukan input dan output diperoleh dari semesta pembicaraan yang terlihat pada tabel 1 berikut.
Tabel 1. Semesta Pembicaraan

\begin{tabular}{|c|c|c|c|}
\hline Variabel & Notasi & $\begin{array}{c}\text { Semesta } \\
\text { Pembicaraan }\end{array}$ & Keterangan \\
\hline $\begin{array}{c}\text { Rumah } \\
\text { Jamur }\end{array}$ & A & {$[0-500]$} & $\begin{array}{c}\text { Jumlah } \\
\text { Produksi }\end{array}$ \\
\hline
\end{tabular}

Dari tabel 1 diatas diperoleh Rumah Jamur sebagai variabel fuzzyfikasi. Rumah Jamur yang digunakan dalam penelitian ini diperoleh dari penelitian-penelitian sebelumnya yang telah diteliti oleh N. Widyastuti and D. Tjokrokusumo dapat terlihat pada tabel 2 berikut.

Tabel 2. Rumah Jamur

\begin{tabular}{|c|c|l|}
\hline $\begin{array}{c}\text { Rumah } \\
\text { Jamur }\end{array}$ & Notasi & \multicolumn{1}{c|}{ Keterangan } \\
\hline 1 & A1 & Kumbung 1 \\
\hline 2 & A2 & Kumbung 2 \\
\hline 3 & A3 & Kumbung 3 \\
\hline 4 & A4 & Kumbung 4 \\
\hline
\end{tabular}

Dari tabel 2 di atas hal yang diperhatikan dan dijadikan sebagai inputan dalam penelitian ini dapat dilihat pada tabel 3 berikut.

Tabel 3. Inputan

\begin{tabular}{|c|c|c|c|c|}
\hline \multicolumn{2}{|c|}{ Variabel } & \multicolumn{2}{c|}{$\begin{array}{c}\text { Himpunan Input } \\
\text { Fuzzy }\end{array}$} & Domain \\
\hline Nama & Notasi & Nama & Notasi & \\
\hline \multirow{3}{*}{ Temperatur } & \multirow{3}{*}{ C1 } & Rendah & R & {$[0-20]$} \\
\cline { 3 - 5 } & & Normal & N & {$[20-27]$} \\
\cline { 3 - 5 } & \multirow{3}{*}{ Kelembapan } & Tinggi & $\mathrm{T}$ & {$[27-28]$} \\
\hline \multirow{3}{*}{ Cahaya } & Kering & $\mathrm{K}$ & {$[0-90]$} \\
\cline { 3 - 5 } & & Lembab & $\mathrm{L}$ & {$[90-95]$} \\
\cline { 3 - 5 } & \multirow{3}{*}{$\mathrm{C} 3$} & Basah & $\mathrm{B}$ & {$[95,100]$} \\
\cline { 3 - 5 } & & Gelap & $\mathrm{G}$ & {$[0-500]$} \\
\cline { 3 - 5 } & Redup & $\mathrm{R}$ & {$[500-1000]$} \\
\cline { 3 - 5 } & Terang & $\mathrm{T}$ & {$[1000-1100]$} \\
\hline
\end{tabular}

Inputan pada tabel diatas penetuan semesta pembicaraan diperoleh dari penelitian-penelitian yang telah dilaksanakan. Contoh pada temperatur normal adalah $20-27^{\circ} \mathrm{C}$. Untuk kelembapan adalah $90-95 \%$. Untuk pencahayaan adalah 500-1000 lux.

Untuk Menentukan output dapat dilihat pada tabel 4 berikut.

Tabel 4. Output

\begin{tabular}{|c|c|c|c|c|}
\hline \multicolumn{2}{|c|}{ Variabel } & \multicolumn{2}{c|}{$\begin{array}{c}\text { Himpunan Input } \\
\text { Fuzzy }\end{array}$} & Domain \\
\hline Nama & Notasi & Nama & Notasi & \\
\hline $\begin{array}{c}\text { Produksi } \\
\text { Jamur }\end{array}$ & \multirow{2}{*}{$\mathrm{C} 4$} & Menurun & $\mathrm{T}$ & {$[0-350]$} \\
\cline { 3 - 5 } & Meningkat & $\mathrm{N}$ & $\begin{array}{c}{[350-} \\
500]\end{array}$ \\
\hline
\end{tabular}

B. Pembentukan Logika Fuzzy

Setelah ditentukan semesta pembicaraan, maka langkah selanjutnya adalah pembentukan logika fuzzy yang terdiri dari proses fuzzyfikasi, penentuan rule, penalaran dan terakhir defuzzyfikasi. 
1. Fuzzyfikasi

Himpunan Fuzzy dan derajat keanggotaan ditentukan berdasarkan data inputan pada tabel 3 berikut penjelasannya.

a. Refresentasi Fungsi Derajat Keanggotaan $(\mu)$ Variabel input Temperatur. Dapat dilihat pada gambar 1 berikut.

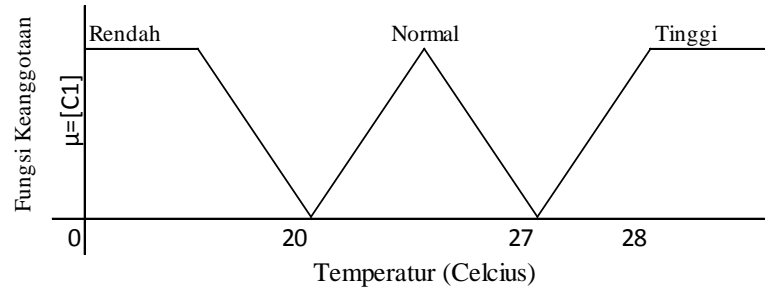

Gambar 1. Refresentasi Fungsi Derajat Keanggotaan $(\mu)$ Variabel Temperatur

b. Refresentasi Fungsi Derajat Keanggotaan $(\mu)$ Variabel input Kelembapan. Dapat dilihat pada gambar 2 berikut.

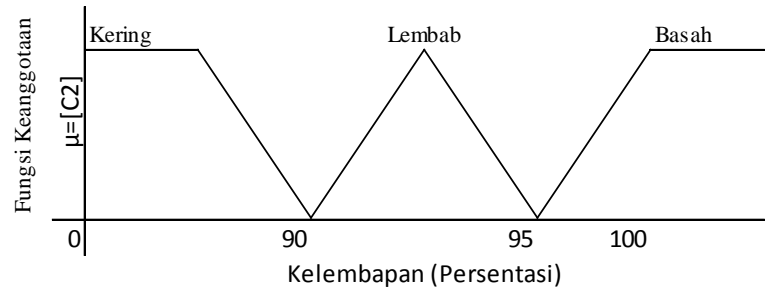

Gambar 2. Refresentasi Fungsi Derajat Keanggotaan ( $\mu)$ Variabel Kelembapan

c. Refresentasi Fungsi Derajat Keanggotaan $(\mu)$ Variabel input Cahaya. Dapat dilihat pada gambar 3 berikut.

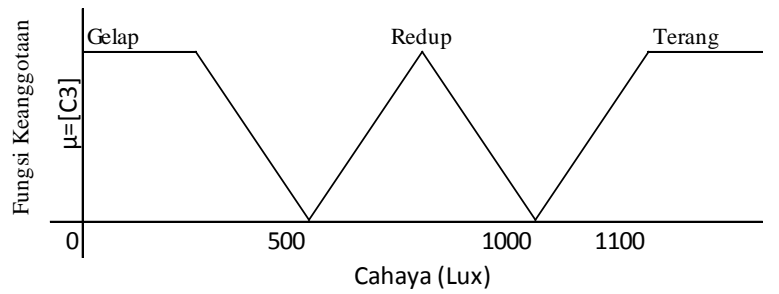

Gambar 3. Refresentasi Fungsi Derajat Keanggotaan

$(\mu)$ Variabel Cahaya

2. Pembentukan Rule

Rules berupa pernyataan kualitatif yang ditulis dalam bentuk IF-THEN, sehingga mudah dimengerti. Rules pada Fuzzy Inference System (FIS) dalam menentukan kualitas jamur terbaik didasari pada jumlah inputan dan jumlah himpunan fuzzy.

3. Penentuan Mesin Inferensi

Penentuan mesin inferensi yang digunakan adalah fungsi MIN (nilai terendah) dari rule-rule yang diperolah.
4. Defuzzyfikasi

Defuzzifikasi yang digunakan adalah metode Centroid.

C. Implementasi Pada Aplikasi Berbasis WEB

Dalam implementasi pada aplikasi dapat dilihat sebagai berikut.

1. Kumbung

Penentuan Kumbung diperoleh dari tabel 2 dan dapat dilihat pada gambar 4 berikut.

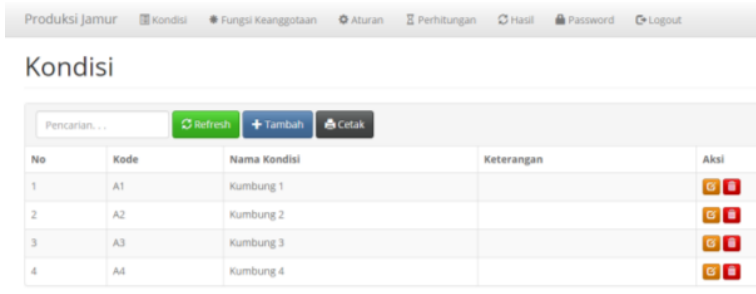

Gambar 4. Kondisi Kumbung

Pada gambar 4 merupakan kondisi kumbung yang diperoleh dari penelitian yang sudah diteliti. Kondisi dapat bertambah sesuai dengan kondisi yang dinginkan.

\section{Fungsi Keanggotaan}

Implementasi fungsi keanggotaan diperoleh dari inputan dan output pada tahap pembentukan fuzzifikasi yang terlihat pada gambar 1, gambar 2 dan gambar 3 . Berikut adalah implementasi pada sistem.

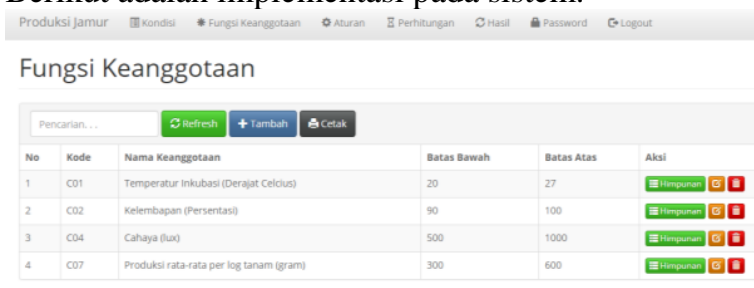

Gambar 5. Fungsi Keanggotaan

3. Aturan Fuzzy

Dalam implementasi aturan fuzzy dapat dilihat pada gambar 6 sebagai berikut.

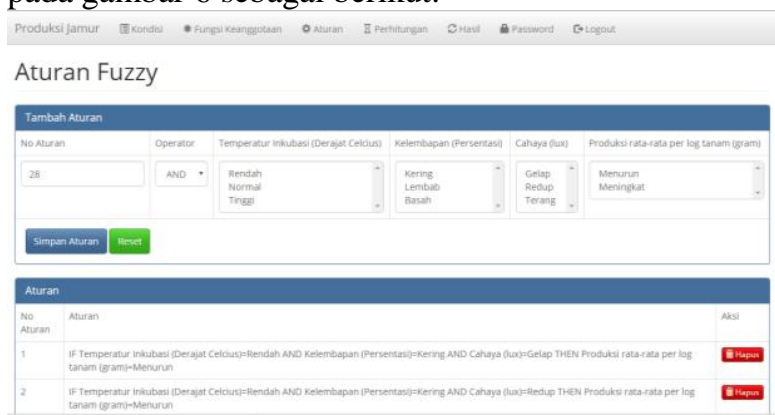

Gambar 6. Aturan Fuzzy

4. Perhitungan Nilai

Dalam implementasi perhitungan nilai dapat dilihat gambar 7 berikut. 


\section{Input Nilai »}

\begin{tabular}{|c|c|c|c|c|}
\hline Kode & $\begin{array}{l}\text { Nilai } \\
\text { C1 }\end{array}$ & $\begin{array}{l}\text { Nilai } \\
\text { C2 }\end{array}$ & $\begin{array}{l}\text { Nilai } \\
\text { C3 }\end{array}$ & Aksi \\
\hline A1 & 19 & 85 & 400 & GUbah \\
\hline $\mathrm{A} 1$ & 19 & 85 & 400 & GUbah \\
\hline $\mathrm{A} 1$ & 19 & 85 & 400 & GUbah \\
\hline A1 & 19 & 85 & 400 & GUbah \\
\hline A2 & 23 & 92 & 750 & GUbah \\
\hline A2 & 23 & 92 & 750 & GUbah \\
\hline A2 & 23 & 92 & 750 & GUbah \\
\hline $\mathrm{A} 2$ & 23 & 92 & 750 & GUbah \\
\hline$A 3$ & 28 & 100 & 1100 & GUbah \\
\hline A3 & 28 & 100 & 1100 & GUbah \\
\hline מ & סר & $10 n$ & $119 n$ & resinata \\
\hline
\end{tabular}

Gambar 7. Input Nilai

5. Hasil

Implementasi untuk hasil dapat dilihat pada gambar 8 berikut.

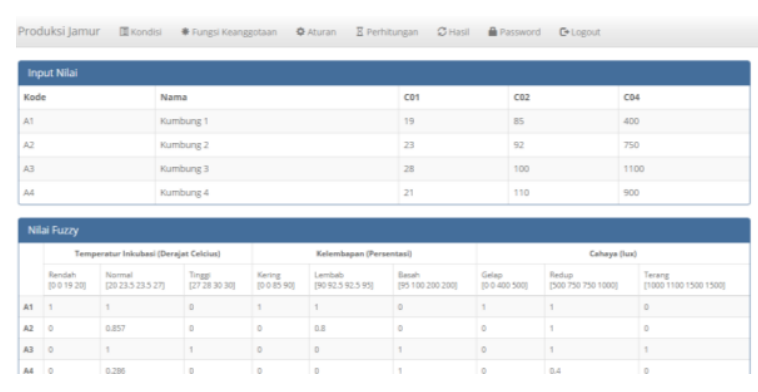

Gambar 8. Hasil

D. Pengujian Sistem

Untuk pengujian sistem dapat inputan diperoleh dari adalah :

1. Kumbung 1

Dalam kondisi :
a. Temperatur
$: 19^{\circ} \mathrm{C}$
b. Kelembapan
$: 85 \%$
c. Cahaya
: 400 lux

2. Kumbung 2

Dalam kondisi :
a. Temperatur
$: 23^{\circ} \mathrm{C}$
b. Kelembapan
$: 92 \%$
c. Cahaya
$: 750 \operatorname{lux}$

3. Kumbung 3

Dalam Kondisi :
a. Temperatur
$: 28^{\circ} \mathrm{C}$
b. Kelembapan : $100 \%$
c. Cahaya : 1100 lux

4. Kumbung 4

Dalam Kondisi :
a. Temperatur
b. Kelembapan : $80 \%$
c. Cahaya : 1100 lux

Berikut adalah pengujian dalam inputan pada sistem.

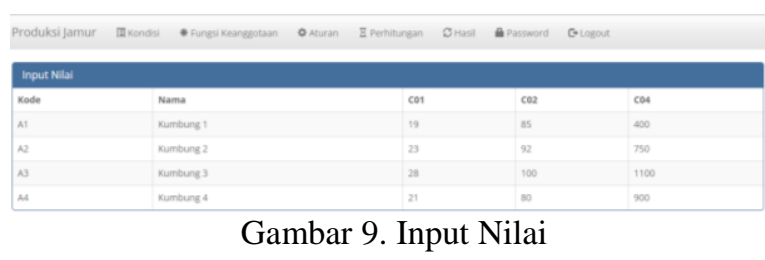

Gambar 9 Menenjukan pengujian input nilai kondisi kumbung. Untuk Nilai Fuzzy dapat dilihat pada gambar 10 berikut.

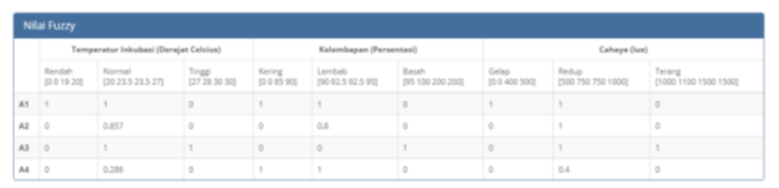

Gambar 10. Nilai Fuzzy

Nilai Fuzzy digunakan untuk menghitung hasil dari inputan sesuai aturan-aturan yang sudah ditentukan. Untuk hasil yang diperoleh dapat terselihat pada gambar 11 berikut.

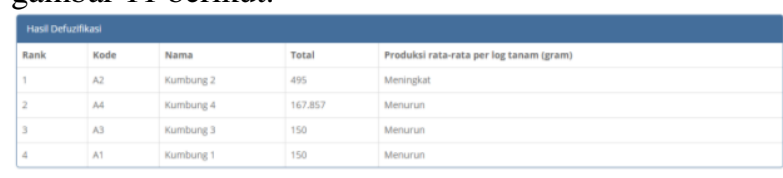

Gambar 11. Hasil Defuzzifikasi

Dari gambar 11 hasil yang telah diperoleh dapat terlihat dan menunjukkan urutan rangking nilai. Terlihat kumbung 2 menempati posisi teratas. Pendukung keputusan yang diperoleh adalah untuk peningkatan produksi jamur tiram dengan kondisi sesuai dengan kumbung 2. 


\section{KESIMPULAN}

Berdasarkan penelitian, implementasi dan pengujian, maka dapat diambil kesimpulan sebagai berikut :

1. Sistem pendukung keputusan peningkatan produksi jamur tiram dapat memberikan kemudahan bagi masyarakat dalam mengontrol temperatur, kelembapan dan cahaya pada kumbung dalam peningkatan produksi jamur tiram.

2. Sistem pendukung keputusan peningkatan produksi jamur tiram dapat memberikan informasi kepada petani dalam mengontrol temperatur, kelembapan, yang mengakibatkan produksi menurun.

\section{DAFTAR PUSTAKA}

[1] N. Widyastuti and D. Tjokrokusumo, "Aspek lingkungan sebagai faktor penentu keberhasilan budidaya jamur tiram," J. Teknol. Lingkung., vol. 9, no. 3, pp. 287-293, 2008.

[2] M. D. Irawan, "Sistem Pendukung Keputusan Menentukan Matakuliah Pilihan pada Kurikulum Berbasis KKNI Menggunakan Metode Fuzzy Sugeno," Media Infotama, vol. 13, no. 1, pp. 27-35, 2017.

[3] A. Suyanto, Searching, Reasoning, Planning, dan Learning (Revisi Kedua). Bandung: Informatika Bandung, 2014.

[4] S. Widodo and V. G. Utomo, "Rancang Bangun Aplikasi Travel Recommender Berbasis Wap Menggunakan Metode Fuzzy Model Tahani," J. Teknol. Inf. dan Komun. STMIK ProVisi Semarang, vol. 5, no. 1, pp. 25-34, 2014.

[5] C. A. R. Al Hasmy, F. Ardila, and Setiwardhana, "Penentuan Peran Dalam Robot Sepak Bola Dengan," EEPIS Final Proj., 2011. 